faculaires centrées sur les taches, la courbe de leur fréquence suit, avec un peu plus de précision que celle des nombres de Wolf-Wolfer, les accidents de la courbe du magnétisme terrestre.

Le Président propose d'examiner la possibilité d'unifier la terminologie relative aux phénomènes chromosphériques principaux: protubérances au bord ou en projection sur le disque, réseau général des flocculi du calcium, flocculi denses et étendus en relation avec les taches.

Après discussion, la Commission estime que des décisions sur ce sujet seraient actuellement prématurées, mais qu'il importe d'engager, dès maintenant, des échanges de vues entre ses divers membres, pour qu'une terminologie plus rationnelle soit élaborée et proposée à l'examen du prochain Congrès de l'Union.

Sur la demande de M. Abetti, la Commission exprime le vœu que l'Observatoire de ZOB-Sè reprenne l'observation des phénomènes chromosphériques et, notamment, celle des protubérances par la méthode du spectroscope à fente large, en vue de la coopération aux Immagini spettroscopiche del bordo solare publiées à Arcetri.

\title{
COMMISSION I2. (SOLAR RADIATION AND SOLAR SPECTROSCOPY.)
}

\author{
President: Prof. Abetti. \\ SECRETARY : Dr M. MinnaERT.
}

The Chairman referred with sorrow to the loss of Dr St John, the former President of the Commission, who died a few months before the meeting.

Solar radiation. The President suggested and Prof. Chapman agreed that it would be interesting to make investigations at high altitudes, especially at wave-lengths of about 2 IOO A.

Solar Spectroscopy. Prof. Russell said that the publication of new tables of the infra red solar spectrum would be delayed by the illnesses of Miss Moore and of Dr Babcock.

Intensity and profile of Fraunhofer lines. After discussion the Commission suggested that measurements of line profiles should be made at different observatories and the results compared, these being made if possible in integrated Solar light, for a few lines selected in the region $\lambda 6200-6300 \mathrm{~A}$. and $\lambda 4000-4200 \mathrm{~A}$.

Variability of Fraunhofer lines. The measurements on this subject, carried out by several investigators (Evershed, Minnaert and his collaborators, Perepelkin), as yet give no definite proof for the existence of such a variability.

Reversing layer (nomenclature). On the suggestion of Menzel to replace the term Reversing layer by Fraunhofer layer, Prof. Russell pointed out that by the name Reversing layer Prof. Young meant the layer in which the bulk of the dark lines are produced, so that there is no reason to choose another name, which has the same meaning.

Spectrum of the Corona. M. Lyot reported on his measurements of the intensity of coronal lines at the Jungfraujoch. He hoped to be able to continue these measurements at the Pic du Midi.

Solar rotation. Prof. Abetti suggested that it would be of great importance for different observatories to choose the same lines, in order to make possible a comparison of the results, and to publish with details the results already obtained for the sake of the study of systematic errors. 
Field of work. After discussion of the suggestions of Drs Minnaert and Babcock, Prof. Dingle pointed out that the field of work of Commission $\mathbf{I}_{4}$ was well defined and large enough to work on. On the other hand Commission I4 would always have the need to continue its work in its well-determined field. Prof. H. H. Plaskett suggested, and the Commission agreed, that questions of technique of spectrophotometry should be left to Commission 36 , while Commission 12 should also treat theoretical questions about the outer layers of both sun and stars.

\title{
COMMISSION I3. (SOLAR ECLIPSES.)
}

\author{
President: Prof. F. J. M. Stratton. \\ SeCRETARY: Dr M. Minnaert.
}

\section{(a) Coming Eclipses}

At the request of the President, Prof. Sotome gave some information about the possibilities of observing in Japan and offered to give any additional details to all those who were interested. In the best central part there was about $40 \%$ probability of a clear sky.

No Russian astronomer being present, Prof. Carroll reported that scientific workers in Russia were anxious to give all possible cooperation; he intended to go himself to Russia this summer, in order to prepare an expedition to Siberia, and he was prepared to get all questions answered which any one should wish to put. Letters about this subject must reach him before the end of August.

This offer was gladly accepted by the President and the whole Commission. To a proposition that the Commission should try to get meteorological and other information and transmit it to the members, Prof. Stratton objected that there was already a commission of the Russian Academiy of Sciences, and that we should not anticipate the pamphlet which would shortly appear.

Dr Jackson reported about the weather conditions in South Africa for the eclipse of 1940 ; these were decidedly excellent; the eclipse came in the nicest part of the year, just after the rain. The only difficulty would be the water supply. For meteorological information one should write to MrWood, of the Union Observatory; other information would be gladly given by the speaker himself.

\section{(b) Expeditions notified for 1936}

In addition to the information already printed in the report of the Commission the following observers notified their intention to organize an expedition: Prof. Donitch would travel to the coast of the Black Sea in Asia Minor; the sun is not high there $\left(20^{\circ}\right)$, but weather prospects are very good. Information should be obtained from the director of the Meteorological Institute at Ankara. Prof. Donitch would travel himself to Turkey in order to prepare this expedition, and would be glad to ask for any information which other expeditions would like to have.

Prof. Stratton thanked Prof. Donitch, and added that information could probably also be obtained from Prof. Freundlich at Istanbul.

Dr Waterfield was not yet sure whether he would go to Russia or to Japan. He would have 6 Ross lenses of short focal distance and great luminosity, so that he would be able to take about I5 photographs of the corona through varying filters.

$$
296
$$

